\title{
Rancang Bangun Lab Komputer Virtual Berbasis Cloud Computing Menggunakan Openstack Pada Jaringan Terpusat
}

\author{
Nelmiawati $^{1 *}$, Nur Cahyono Kushardianto ${ }^{2 *}$, Ahmad Hamim Tohari ${ }^{3 *}$, Yan Prada Hasibuan ${ }^{4} *$, \\ Dwi Ely Kurniawan ${ }^{5 * *}$ \\ * Teknik Informatika, Politeknik Negeri Batam \\ ** Teknik Multimedia Jaringan, Politeknik Negeri Batam \\ $\underline{\text { mia@ } @ \text { polibatam.ac.id }}{ }^{1}$, anung@polibatam.ac.id ${ }^{2}, \underline{\text { hamim @ polibatam.ac.id }}^{3}, \underline{\text { dwialikhs@ }}^{\text {polibatam.ac.id }}{ }^{5}$
}

\section{Article Info}

\section{Article history:}

Received 2018-04-01

Revised 2018-06-21

Accepted 2018-07-01

Keyword:

Lab Komputer Virtual, cloud computing, Openstack.

\begin{abstract}
Politeknik Negeri Batam is one of campuses that taught students more on hands on skill based. Students are faced with a big number of hands on skills task than theory. However, access to the lab is limited. Virtual computer lab using Cloud Computing technology is one of solution to overcome this limitation. The research has been conducted on designing Cloud Computing's virtual computer lab using OpenStack on a centralized network. Tests were performed with specific server specifications and OpenStack platform. Through case studies of object-based programming courses, result shows that the server used during testing can run virtual computer lab with 9 computers very well.
\end{abstract}

\section{Pendahuluan}

Politeknik Negeri Batam sebagai lembaga pendidikan vokasi memandang laboratorium komputer sebagai sarana pembelajaran yang vital. Terlebih terhadap jurusan Teknik Informatika yang merupakan salah satu jurusan yang membutuhkan keberadaan ruang laboratorium untuk semua mata kuliah praktikum. Namun akses mahasiswa ke lab komputer hanya dapat dilakukan pada sesi perkuliahan. Terbatasnya jumlah lab komputer serta makin bertambahnya jumlah mahasiswa menyebabkan padatnya jadwal penggunaan ruang laboratorium tersebut.

Perkembangan teknologi saat ini sudah sangat pesat. Tidak lagi mengenal batas ruang dan waktu. Hal itu tampak dari munculnya teknologi Cloud Computing atau Komputasi Awan. Dimana perkembangan teknologi tersebut dapat diartikan sebagai infrastruktur, aplikasi dan penyimpanan yang dapat diakses secara terpusat di satu tempat (server), tidak lagi pada komputer client.

Salah satu penerapan teknologi Cloud Computing dalam dunia pendidikan ialah adanya Virtual Lab (Vlab) [1-3]. Vlab merupakan suatu proses pembelajaran elektronik dengan menggunakan simulasi komputer. Vlab dapat menjadi media yang digunakan untuk membantu memahami suatu pokok bahasan dan dapat menjadi solusi keterbatasan atau keterbatasan perangkat laboratorium.
Penelitian sebelumnya telah mengembangkan lab komputer virtual berbasis cloud computing menggunakan ovirt [4], proxmox [5]. Pada server proxmox komputer virtual yang berhasil dibuat dan dijalankan berjumlah 15 , sedangkan pada server ovirt berjumlah 20 komputer virtual [1]. Penelitian ini mencoba mengembangkan virtual lab menggunakan Openstack pada jaringan terpusat.

\section{METODE}

Metode penelitian meliputi analisis kebutuhan, perancangan dan implementasi serta mengevaluasi hasil perancangan sistem yang dikembangkan. Persyaratan minimal untuk instalasi dan penggunaan Openstack bervariasi, sesuai dengan skala lingkungan kerjanya. Berikut persyaratan minimal untuk instalasi openstack dengan menggunakan 1 buah komputer komputer server:

- Sebuah PC dengan Sistem Operasi Centos 7.2

- Prosesor 64 bit yang mendukung virtualisasi ( AMD$\mathrm{V}$ atau Intel VT hardware virtualization)

- Minimun RAM 2 GB

- Tambahan RAM disesuaikan dengan instance yang akan dibuat. 
- $\quad$ Minimum harddisk $20 \mathrm{~GB}$

- Tambahan alokasi harddisk disesuaikan dengan kebutuhan dan jumlah instance yang akan dibuat.

- Sebuah Network Interface Card/Ethernet dengn kecepatan $1 \mathrm{Gbps}$

Spesifikasi server yang digunakan dalam penelitian ini, dengan membandingkan rekomendasi Red Hat di situs resminya dapat dilihat pada tabel berikut.

TABEL I

SPESIFIKASI SERVER

\begin{tabular}{|c|c|c|c|}
\hline No & Parameter & Nilai & Kesesuaian \\
\hline 1 & $\begin{array}{l}\text { Sistem } \\
\text { Operasi } \\
\end{array}$ & $\begin{array}{l}\text { CentOS Linux release } \\
7.2 .1511\end{array}$ & Sesuai \\
\hline 2 & Prosesor & $\begin{array}{l}\text { Intel }{ }^{\circledR} \text { Xeon } ® \text { Processor } \\
5130\end{array}$ & Sesuai \\
\hline 3 & RAM & $16 \mathrm{~GB}$ & $\begin{array}{l}\text { Diatas } \\
\text { Rekomendasi }\end{array}$ \\
\hline 4 & Hardisk & $250 \mathrm{~Gb}$ & $\begin{array}{l}\text { Diatas } \\
\text { Rekomendasi } \\
\end{array}$ \\
\hline 5 & Ethernet & $\begin{array}{l}\text { Broadcom NetXtreme } \\
\text { BCM5752 Gigabit } \\
\text { Ethernet PCI Express }\end{array}$ & $\begin{array}{l}\text { Sesuai } \\
\text { Rekomendasi }\end{array}$ \\
\hline
\end{tabular}

Komputer virtual yang dibuat untuk memenuhi spesifikasi kebutuhan pada mata kuliah pemrograman berbasis objek, dengan sistem operasi windows 7 Ultimate 64 bit. Rekomendasi dari Ovirt untuk Windows 7 adalah sebagai berikut:

- VirtIO Interface Disk

- VirtIO, Bridged Network Interface

- Minimum 1 GB RAM

Berdasarkan rekomendasi tersebut, komputer virtual dibuat dengan spesifikasi sebagai berikut

TABEL II

SPESIFIKASI KOMPUTER VIRTUAL

\begin{tabular}{|c|l|l|}
\hline No & Parameter & Nilai \\
\hline 1 & Processor & $\begin{array}{l}\text { KVM 64 2 Core } \\
\text { Processor }\end{array}$ \\
\hline 2 & RAM(MB) & 1536 \\
\hline 3 & Harddisk & 25 GB \\
\hline 4 & NIC & $\begin{array}{l}\text { Redhat Virtio Ethernet } \\
\text { Adapter }\end{array}$ \\
\hline
\end{tabular}

Kemudian perangkat lunak yang diinstall pada virtual komputer sesuai kebutuhan penelitian adalah:

- Java Development Kit (jdk) versi 7

- $\quad$ Netbeans IDE versi 7

- $\quad$ iReport 5.00 dan Jasperreports 5.01

Sedangkan komputer klien yang digunakan untuk mengakses lab virtual pada server memiliki spesifikasi berbeda, mulai dari kapasitas RAM yang berbeda, kapasitas Harddisk hingga hingga Processor yang berbeda juga. Sementara perangkat lunak yang dibutuhkan adalah, sistem operasi windows 7 dan aplikasi browser Mozilla Firefox atau Google Chrome. Browser digunakan untuk mengakses komputer virtual pada server.

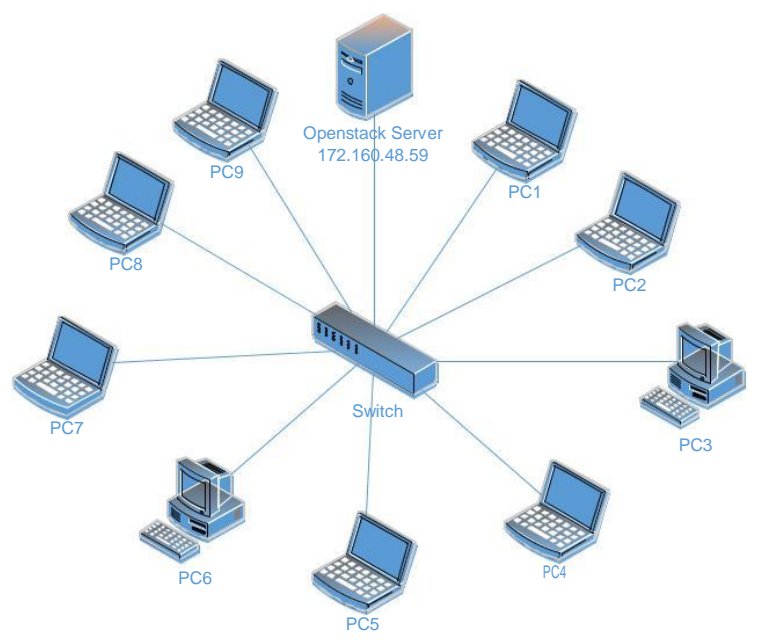

Gambar 1. Topologi Jaringan Vlab

Spesifikasi jaringan menggunakan Switch merek HP ProCurve 2520 1000Mbps, kabel jaringan yang digunakan UTP CAT 5E 100Mbps, Subnet Mask 255.255.252.0, Default Gateway 172.160.50.254.

\section{ImPlementasi PeranCangan}

\section{A. Instalasi Cloud Server}

Platform yang digunakan pada server adalah Openstack. Perbedaan dengan proxmox, dimana openstack tidak bersama didalam sebuah sistem operasi. Openstack harus dijalankan diatas sistem operasi yang didukung Ubuntu, Red Hat Enterprise Linux, CentOS atau OpenSuse. Pada percobaan ini Openstack dijalankan pada Centos 7.2 dan menggunakan Openstack Mitaka.

Proses instalasi Openstack Mitaka adalah sebagai berikut.

- Konfigurasi file /etc/hosts dan tambahkan baris hostname untuk server Openstack

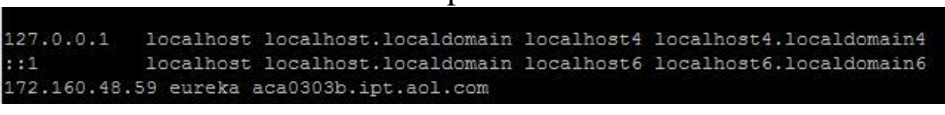

Gambar 2. Konfigurasi file hosts

- Konfigurasi file /etc/sysconfig/network-scripts/ifcfgbr-ex dan /etc/sysconfig/network-scripts/ifcfgenp11s0 untuk pengaturan jaringan host

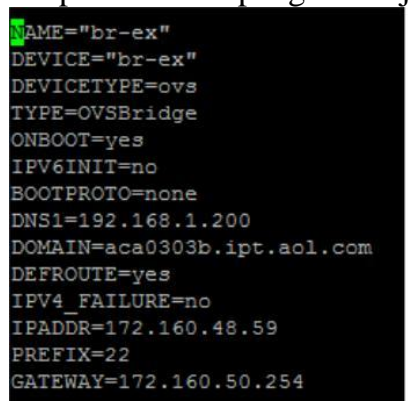

TYYPE $=$ ovsPort BOOTPROTO="none" IPV 6 INIT $="$ no" NAME $=$ "enp $11 \mathrm{son}$ DEVICE $=$ "enp11so" ONBOOT $=$ "yes" DEVICETYPE $=$ "OVg" OVS_BRIDGE=br-ex

Gambar 3. Konfigurasi Bridge dan Ethernet 
- Konfigurasi DNS pada file/etc/resolv.conf

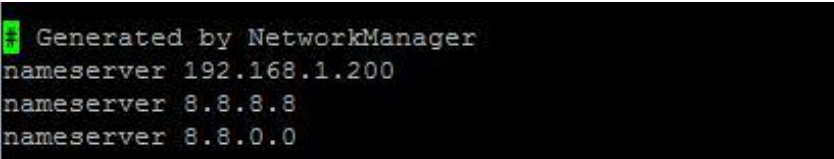

Gambar 4. Konfigurasi DNS

- Instalasi repository openstack

\# yum install -y https://rdoproject.org/repos/rdorelease.rpm

- Update package \# yum update -y

- Instalasi packstack installer

\# yum install -y openstack-packstack

- Langkah akhir ialah, jalankan opackstack untuk menginstall openstack

\# yum install -y openstack-packstack

\section{B. Konfigurasi Komputer Virtual}

Untuk membuat komputer virtual pada server Openstack, dapat dilakukan dengan langkah langkah sebagai berikut.

- Masuk ke halaman web admin server Openstack: http://172.160.48.59

- Masukkan username dan password dari user admin
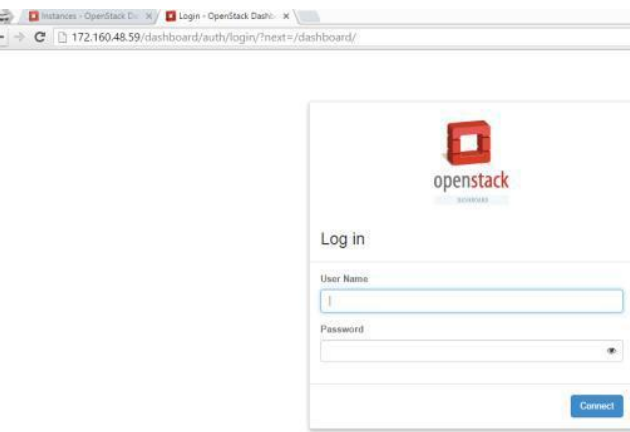

Gambar 5. Halaman awal Openstack

- Mempersiapkan environment untuk new VM

- Mengatur Network Environment. Klik menu admin $\rightarrow$ Systems $\rightarrow$ networks

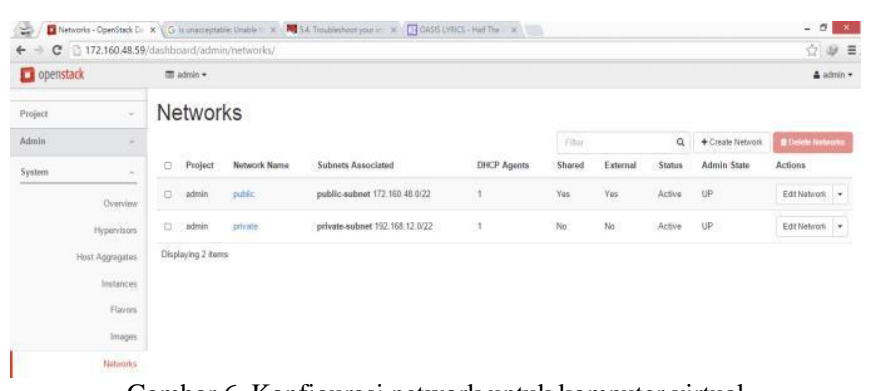

Gambar 6. Konfigurasi network untuk komputer virtual

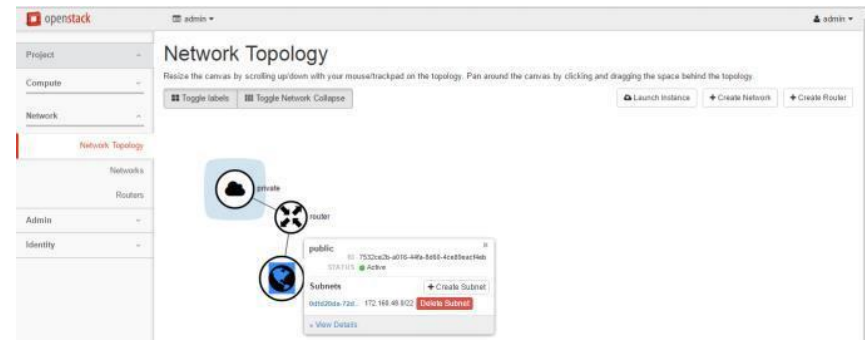

Gambar 7. Konfigurasi network untuk komputer virtual

- Mengatur flavor (hardware yang

diasosiasikan/ditempatkan ke instances atau virtual machine yang akan dibuat. Hal ini dapat berupa RAM, CPUs, dan Disks).

Create Flavor

\begin{tabular}{l} 
Flavor Information ${ }^{*}$ Flavor Access \\
Name * \\
IDO \\
auto \\
RCPUS ${ }^{*}$ \\
RAM (MB) \\
\hline
\end{tabular}

havors define the sizes for RAM, disk, number of cores, fresources and can be selected when users ploy instances.

Gambar 8. Konfigurasi Flavor

- Mengatur Access dan Security Security Group dan Keypair

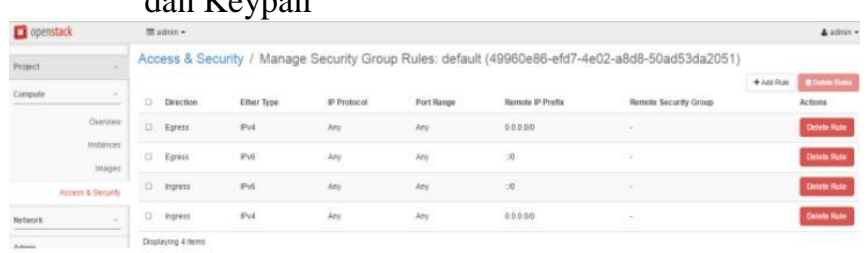

Import Key Pair

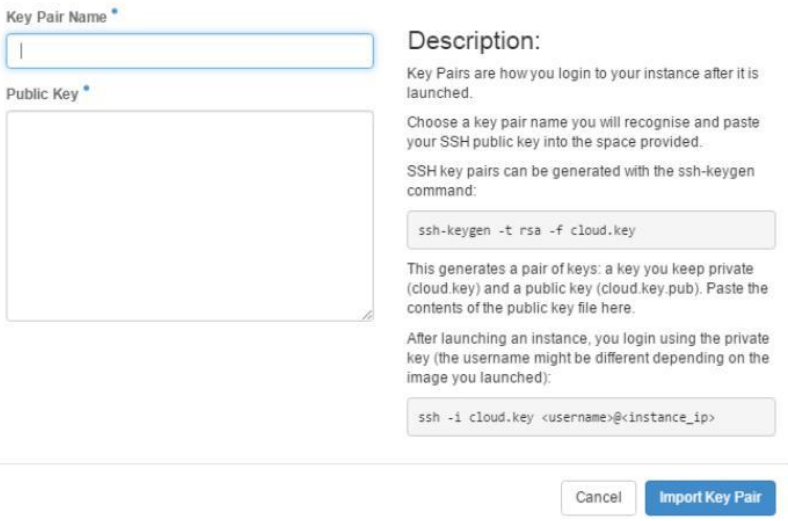

Gambar 9. Konfigurasi Security group dan Keypair

- Mempersiapkan image windows 7 dalam format qcow2 


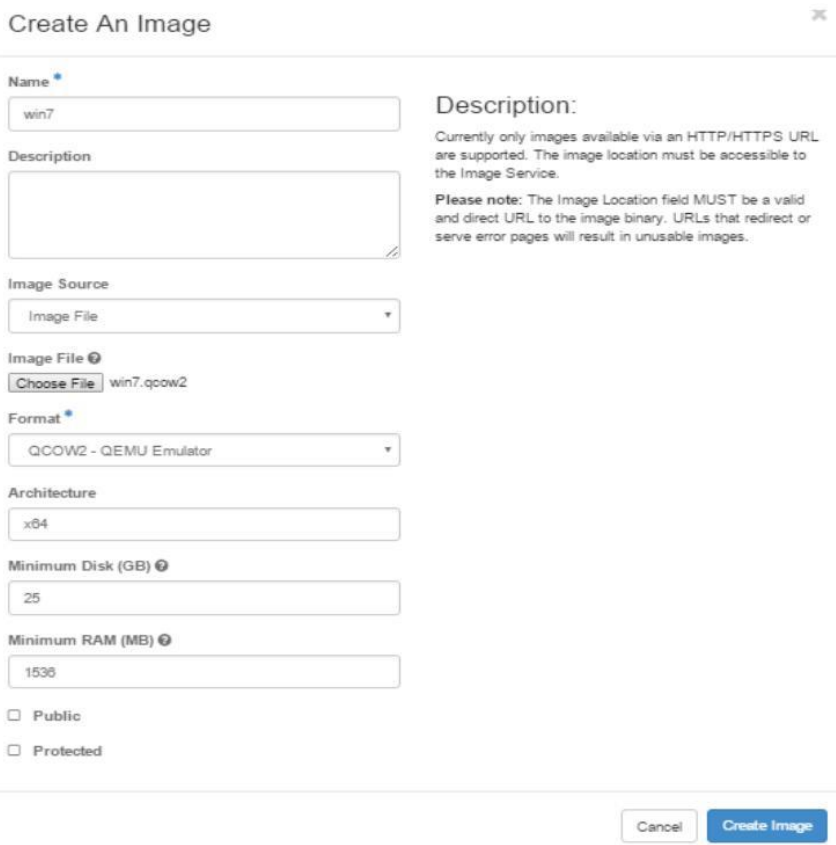

Gambar 10. Menyiapkan image windows

- Membuat Instances

Klik menu admin $\rightarrow$ Compute $\rightarrow$ instance $\rightarrow$ launch instance, isi formulir yang sesuai dengan lingkungan yang telah dipersiapkan sebelumnya. Kemudian klik launch

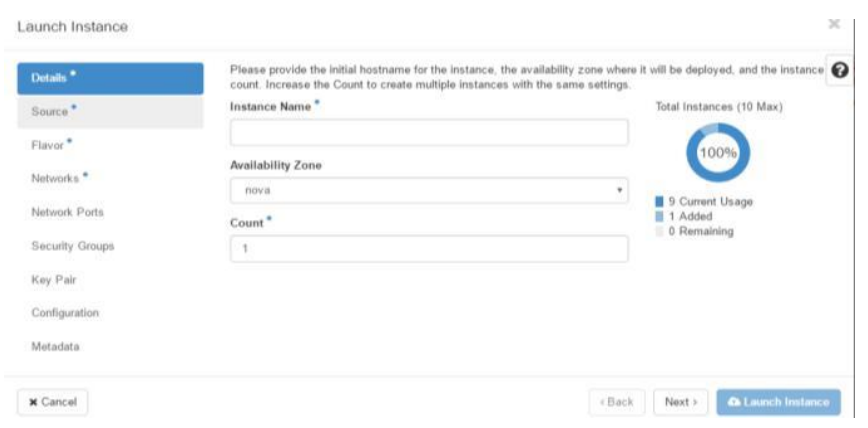

Gambar 11. Membuat instances/ komputer virtual

- Tampilan setelah VM / Instances selesai dibuat

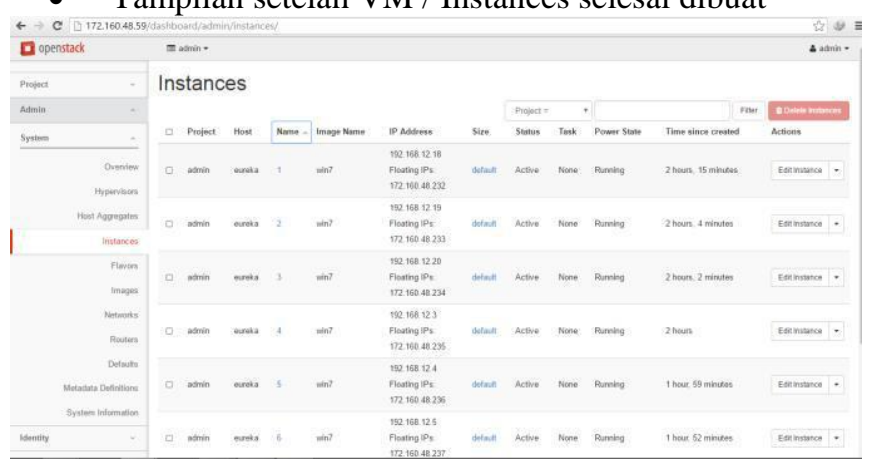

Gambar 12. Instances / komputer virtual berhasil dibuat

\section{ANALISIS dan PENGujIan}

Openstack dikembangkan oleh Ubuntu namun tidak hanya dapat berjalan diatas sistem operasi berbasis Ubuntu melainkan dapat juga berjalan di sistem operasi dari distro lain seperti Red Hat. Pada pengujian kali ini menggunakan Openstack di sistem operasi Centos 7.2 dari distro Red Hat. Dalam melakukan pengujian dibutuhkan beberapa perangkat lunak pendukung seperti Italc, Macro Recorder dan Camstudio. Macro recorder digunakan untuk menjalankan komputer virtual, aplikasi netbeans serta mengeksekusi algoritma. Italc digunakan untuk mengeksekusi skenario macro yang telah dibuat secara bersama pada beberapa komputer. Aktifitas yang dilakukan secara otomatis dengan macro, direkam untuk diambil datanya dengan aplikasi Camstudio.

\section{A. Pengujian StartUp}

Pengujian direncanakan sampai 9 komputer virtual. Berikut adalah grafik rata-rata hasil pengujian waktu startup yang dilakukan sebanyak 6 kali mulai dari 1 sampai 9 komputer virtual yang dijalankan secara bertahap komputer virtual. Pengujian hanya dapat menjalankan sampai 9 komputer virtual, hal ini disebabkan oleh keterbatasan smber daya server.

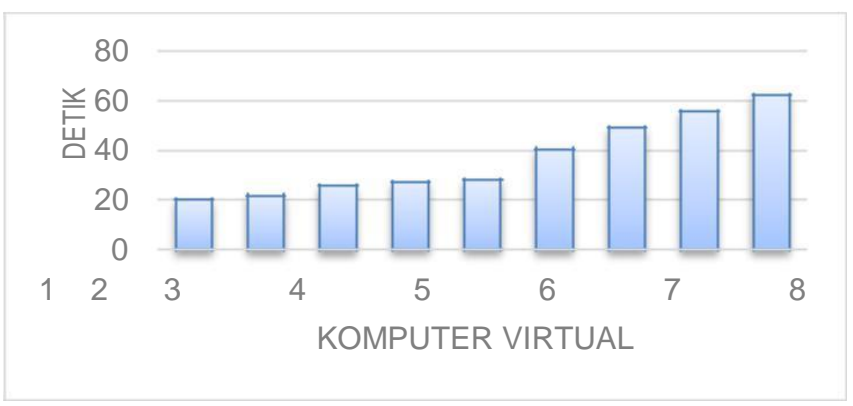

Gambar 13. Grafik rata-rata waktu startup computer virtual

Gambar 13 menjelaskan bahwa waktu startup 1 sampai 9 komputer virtual secara bersama berkisar antara 20 sampai 62 detik. Untuk menjalankan 9 komputer virtual saja sudah membutuhkan waktu lebih dari 1 menit. Sedangkan secara normal sistem operasi windows 7 dan aplikasi yang terpasang, hanya butuh waktu kurang dari 1 menit bagi komputer virtual untuk startup, sedangkan untuk menjalankan lebih dari 9 komputer virtual membutuhkan waktu lebih dari 1 menit. Artinya catatan waktu yang dibutuhkan untuk menjalankan 30 komputer virtual akan cukup lama.

Pengujian menjalankan komputer virtual ini dilakukan sebanyak 6 kali. Variasi data pada tiap pengujian dapat dilihat pada grafik dibawah ini. 


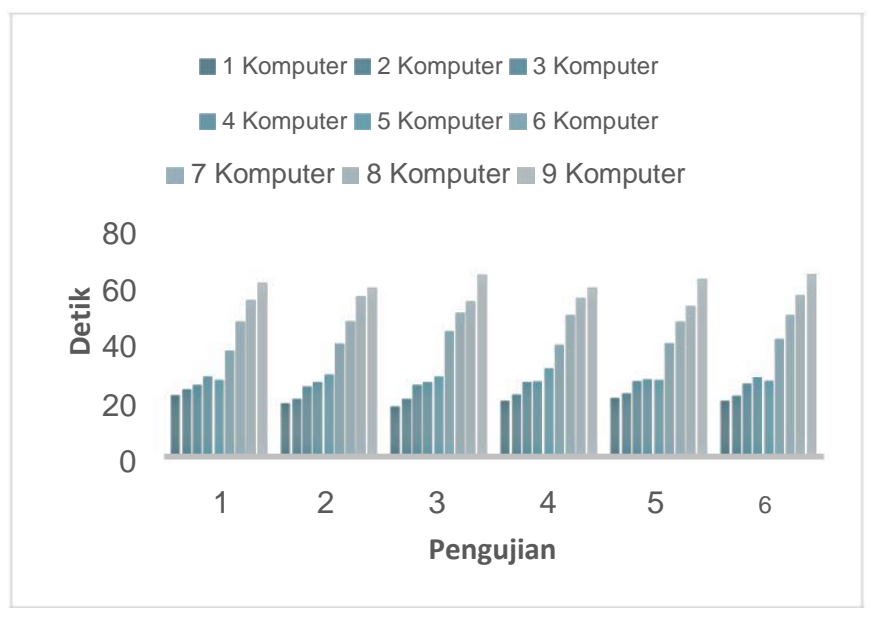

Gambar 14. Grafik Pengujian Startup Komputer Virtual

Gambar 14 menjelaskan bawah kecenderungan waktu startup tiap pengujian cenderung stabil. Grafik menunjukkan semakin banyak komputer virtual yang dijalankan, maka perlambatan waktu startup semakin besar.

\section{B. Penggunaan RAM}

RAM cukup mempengaruhi cepat lambatnya waktu startup komputer virtual. Untuk mengecek penggunaaan RAM dengan menggunalan command free $-m$. Pada saat menjalankan komputer virtual sekaligus, penggunaan RAM mencapai $88 \%$.

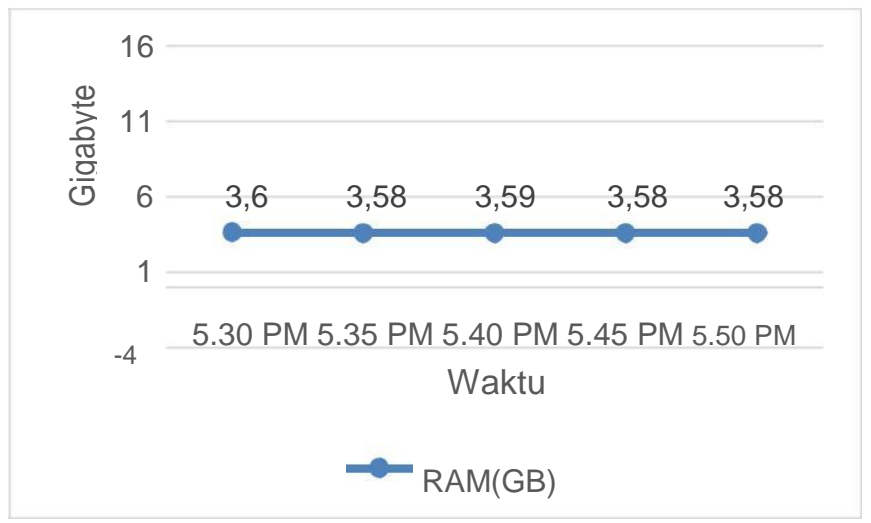

Gambar 15. Grafik Penggunaan RAM sebelum menjalankan Komputer Virtual

Berdasarkan Gambar 15 bahwa, saat komputer virtual dalam keadaan mati, penggunaan RAM stabil disekitaran 3.9 GB. Penggunaan RAM tersebut dipengaruhi oleh service service yang berjalan seperti Nova dan Neutron.

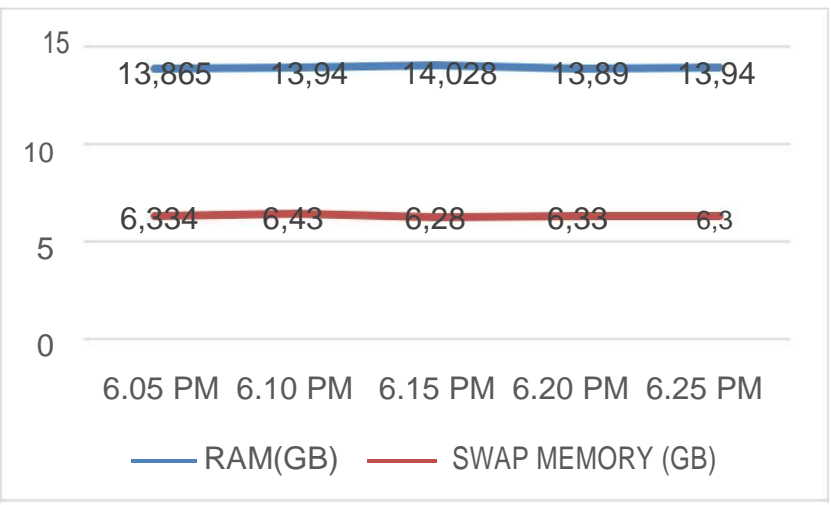

Gambar 16. Grafik Penggunaan RAM setelah menjalankan 9 komputer virtual

Setelah menjalankan 9 komputer virtual, penggunaan RAM dan Swap memory melonjak drastis mencapai 88 persen dari memori total. Hal ini disebabkan alokasi memori untuk setiap komputer virtual yang mencapai 1.5 GB. Penggunaan memori yang cukup besar tersebut sangat berpengaruh terhadap lambatnya waktu startup komputer virtual.

\section{Pengujian Menjalankan Aplikasi Netbeans}

Pengujian menjalankan aplikasi Netbeans untuk mengetahui waktu yang dibutuhkan komputer virtual untuk menjalankan aplikasi Netbeans. Aplikasi ini merupakan aplikasi utama yang digunakan pada mata kuliah Pemrograman Berorientasi Objek yang menjadi studi kasus pada penelitian ini. Aplikasi Netbeans yang akan dijalankan sesuai dengan spesifikasi yang sudah dijelaskan sebelumnya, dan juga diinstal bersamaan dengan modul dan plugin yang dibutuhkan.

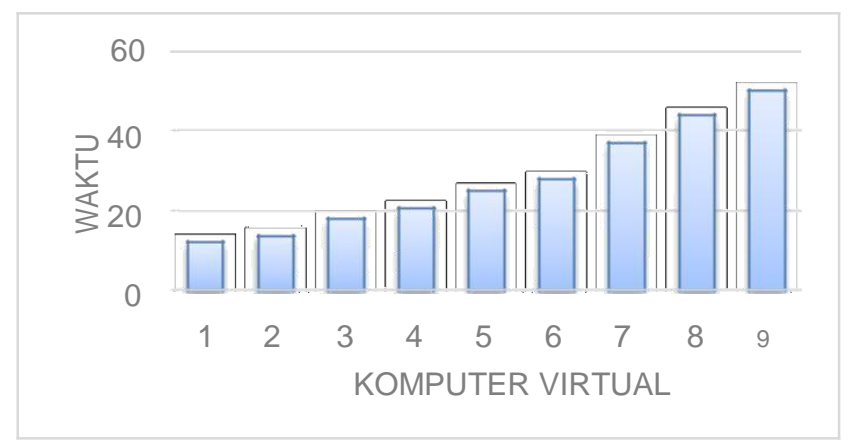

Gambar 17. Grafik Waktu rata-rata menjalankan aplikasi netbeans

Gambar 17 menjelaskan bahwa dapat dilihat kecenderungan waktu untuk menjalankan aplikasi Netbeans cukup stabil. Tidak ada lonjakan yang drastis dalam menjalankan aplikasi tersebut. Dapat disimpulkan bahwa aplikasi Netbeans berjalan dengan baik. Detail waktu untuk menjalankan aplikasi tersebut selama 6 kali pengujian dapat dilihat pada gambar 18 berikut. 


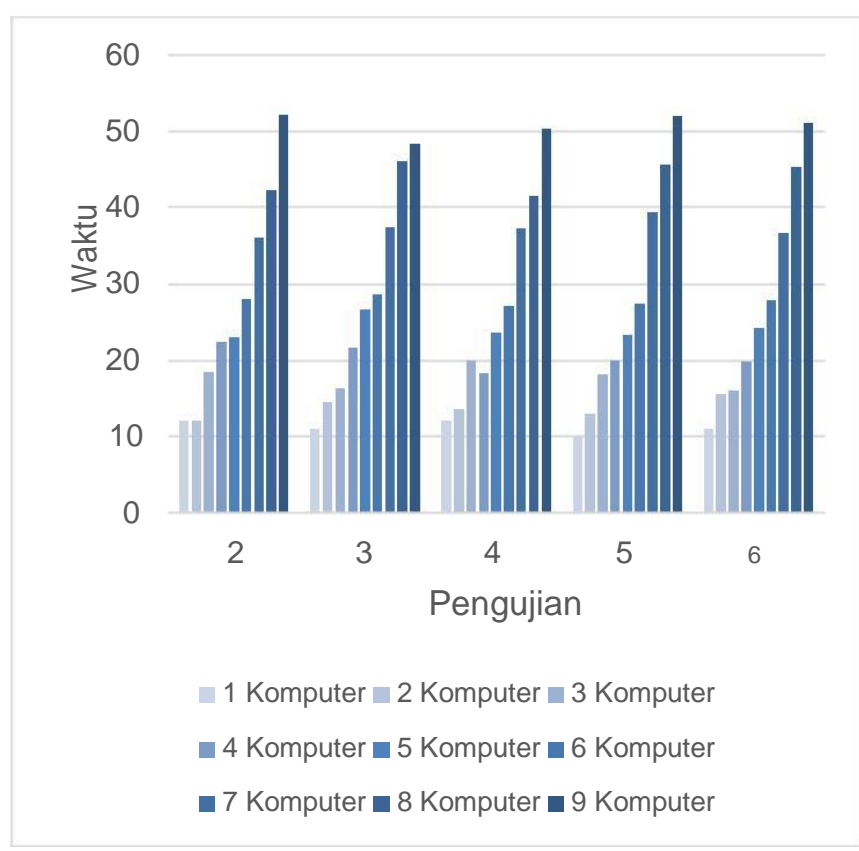

Gambar 18 Grafik waktu pengujian menjalankan Netbeans

Gambar 18 menunjukkan bahwa, terlihat ketidak stabilan terjadi saat menjalankan sedikit ( 1 sampai 5 ) komputer virtual . Namun ketika menjalankan banyak ( 6sampai 9 ) komputer virtual, grafik mulai stabil. Hal ini berarti openstack cukup stabil untuk penggunaan dalam skala yang besar.

\section{Pengujian Compile Agoritma}

Pengujian yang dilakukan ialah pengujian compiling algoritma sieve of atkin atau algoritma untuk menemukan bilangan prima dengan limit $\mathrm{n}$, dalam pengujian ini $\mathrm{n}$ memiliki nilai 178.837.830. Pengujian dilakukan untuk mengetahui berapa lama waktu yang dibutuhkan untuk mengeksekusi program yang berisi algoritma tersebut. Pengujian juga dilakukan untuk mengetahui ketahanan server.

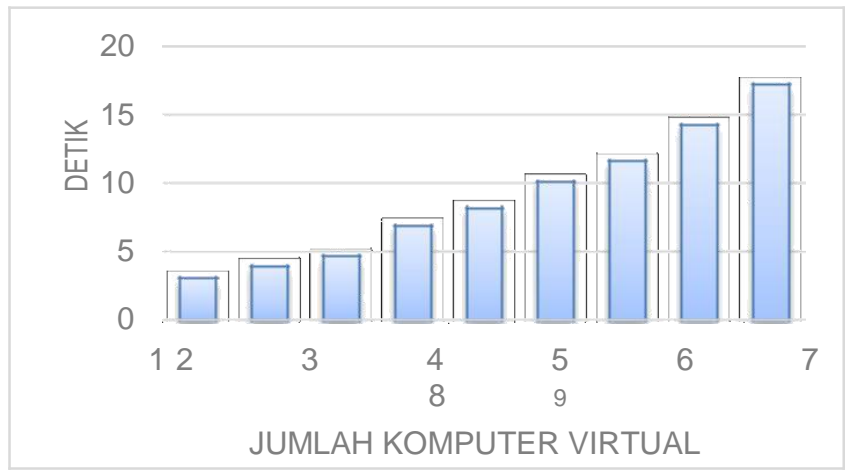

Gambar 19. Grafik waktu rata-rata compiling algoritma sieve of atkin

Gambar 19 menunjukkan bahwa untuk melakukan compiling program algoritma sieve of atkin pada 1 komputer virtual hanya membutuhkan waktu tidak lebih dari 3 detik.
Terlihat juga peningkatan waktu compiling yang cenderung stabil.

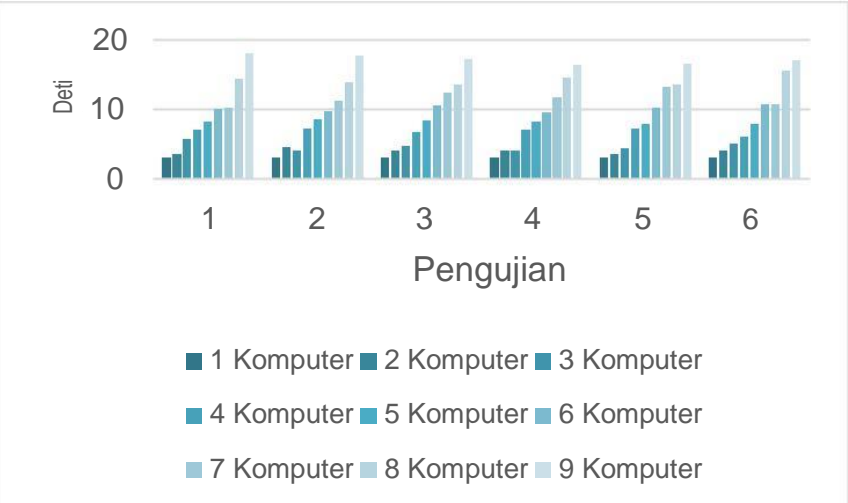

Gambar 20. Grafik waktu setiap pengujian algoritma Sieve of Atkin

Gambar 20 menunjukkan bahwa saat menjalankan program berisi algoritma sieve of atkin mengalami peningkatan yang cukup stabil, namun waktu yang dibutuhkan cenderung masih terlalu besar. Hal ini disebabkan kemampuan processor yang digunakan saat percobaan cukup terbatas.

\section{KESIMPULAN}

Hasil penelitian yang diperoleh dari penelitian ini dapat dibandingkan dengan hasil penelitian sebelumnya, server Proxmox [1] dan server Ovirt [2] menunjukkan bahwa;

1) Jika diukur dari sisi waktu startup, server proxmox dalam menjalankan 5 komputer virtual membutuhkan waktu sekitar 17 detik, server ovirt membutuhkan waktu 20 detik dan server openstack membutuhkan waktu sekitar 26 detik. Untuk menjalankan 10 komputer virtual, proxmox membutuhkan 29 detik serta ovirt 145 detik. Sedangkan server openstack membutuhkan waktu 50 detik dalam menjalan 9 komputer virtual. Dari hasil tersebut kita dapat menyimpulkan bahwa untuk menjalankan 10 komputer virtual, server proxmox menjadi pilihan terbaik.

2) Jika diukur dari waktu menjalankan aplikasi netbeans, server proxmox membutuhkan waktu 18 detik, server ovirt 25,6 detik dan openstack membutuhkan waktu 24,6 detik dalam menjalankan aplikasi netbeans pada 5 komputer virtual secara bersamaan. Sedangkan saat menjalankan aplikasi netbeans pada 10 komputer virtual, server proxmox membutuhkan waktu sebanyak 34 detik, server ovirt 45 detik. Sedangkan server openstack membutuhkan waktu 50 detik untuk menjalankan aplikasi netbeans pada 9 komputer virtual.

3) Sedangkan jika diukur dari waktu compiling program berisi algoritma Sieve of Atkin, server proxmox membutuhkan waktu 8.3 detik, server ovirt 8.8 detik, serta server openstack membutuhkan waktu 8.3 detik dalam melakukan compiling pada 5 komputer virtual secara bersamaan. Sedangkan pada 10 komputer virtual secara bersamaan, server proxmox membutuhkan waktu 
18 detik, dan server ovirt 15.4 detik. Sedangkan server openstack membutuhkan waktu sekitar 15,3 detik dalam melakukan compiling.

4) Maka dapat disimpulkan, secara garis besar server proxmox yang paling baik dalam pemanfaatan teknologi lab komputer virtual. Namun hasil ini belum cukup valid mengingat spesifikasi server yang digunakan berbeda. Server yang digunakan proxmox menggunakan processor 8(octa) core serta RAM $24 \mathrm{~Gb}$ sedangkan openstack menggunakan processor 4 (quad) core serta RAM 16 Gb.

\section{DAFTAR PUSTAKA}

[1] Beloglazov, A. and Buyya, R., 2015. OpenStack Neat: a framework for dynamic and energy-efficient consolidation of virtual machines in OpenStack clouds. Concurrency and Computation: Practice and Experience, 27(5), pp.1310-1333.

[2] Bonner, S., Pulley, C., Kureshi, I., Holmes, V., Brennan, J. and James, Y., 2013, October. Using OpenStack to improve student experience in an HE environment. In Science and Information Conference (SAI), 2013 (pp. 888-893). IEEE.

[3] Cenka, B.A.N. and Hasibuan, Z.A., 2013, March. Enhancing educational services using cloud technology. In Information and Communication Technology (ICoICT), 2013

International Conference of (pp. 155-160). IEEE.

[4] Sumarto, S., Thohari, A.H. and Apriyani, M.E., 2014. Rancang Bangun Lab Komputer Virtual Berbasis Cloud Computing Menggunakan Ovirt Pada Jaringan Terpusat. Jurnal Integrasi, 6(1), pp.72-76.

[5] Thohari, A.H., Sumarto, S. and Apriyani, M.E., 2014. Rancang Bangun Lab Komputer Virtual Berbasis Cloud Computing Menggunakan Proxmox Pada Jaringan Terpusat. Prosiding Seminar Applied Business and Engineering Conference (ABEC) 2014.

[6] Kurniawan, D.E. and Surur, M.N., 2016. Perancangan Sistem Pengamanan Sepeda Motor Menggunakan Mikrokontroler Raspberry Pi dan Smartphone Android. Jurnal Komputer Terapan, 2(2), pp.93-104.

[7] Kurniawan, D.E., 2017. Push Notification System Pada Prototype Kendali Listrik Rumah. CESS (Journal of Computer Engineering, System and Science), 2(2), pp.89-92.

[8] Kurniawan, D.E., 2017. Simulasi Perhitungan Tarif Pada Pemandu Wisata Berbasis Perangkat Bergerak. CESS (Journal of Computer Engineering, System and Science), 2(1), pp.1216.

[9] Li, P., 2010. Centralized and decentralized lab approaches based on different virtualization models. Journal of Computing Sciences in Colleges, 26(2), pp.263-269.

[10] Purbo, Ono. W, "Membuat Sendiri Cloud Computing Server Menggunakan Open Source”, Yogyakarta: Andi Offset, 2012 